\title{
UNDERSTANDING FATWAHS \& THE CONCERNS OF IRAQI YOUTH TODAY
}

\begin{abstract}
Muslims believe that Qur'anic revelations and the sayings (or hadith) of the Prophet Muhammad provide a code of life for this world, and the hereafter. Through the Holy Qur'an, His Prophet, and the Prophet's Progeny, Allah informed Muslims that it is incumbent upon them to both pursue knowledge, and to act upon it with wisdom. In an attempt to obey this command of the Almighty, followers of Islam who seek to understand Divine Scriptures with due diligence also eventually realise the limits to their understanding, even when endeavouring to decode the apparently simplest of Qur'anic verses, as they often have an underlying complexity to their exegesis. Thus, unlike Sunni Muslims, the Shi'a followers of the Ahlulbayt appreciate both the importance and necessity of taqlìd - that is, deferring to appointed jurisprudents for learned and scholarly interpretations of the Holy Texts, the teachings of the Prophet Muhammad and what are considered to be his infallible descendants from his daughter, Fatima Zahra. However, to what extent are the edicts, or fatwahs, issued by contemporary Islamic jurisprudents in alignment with the beliefs and concerns of the youth of today, specifically Iraqis?
\end{abstract}

KEYWORDS: Islamic Jurisprudents, Marāji, Mujtahid, edicts, fatwahs, taqlīd, Iraqi Youth, concerns.

1 s.butt@bham.ac.uk 


\section{INTRODUCTION}

According to a study commissioned by Oxfam (Massella, 2017), 61\% of the Iraqi population are under the age of 24 , of which $20 \%$ are aged between 15 and 24. Thus, naturally, it is imperative to understand the matters which are most pertinent to the Iraqi youth, as this demographic are the future of the nation which is undergoing considerable political turmoil. Recent reports suggest that drug abuse \& depression (Bassem, 2014); religious \& tribal polarisation (Williams, 2017); and political displacement \& insecurity (UN Assistance Mission for Iraq, 2017) are among the main issues and struggles that some of the younger generation of Iraqis are grappling with today.

This paper aims to present the findings of empirical research conducted through a questionnaire issued to Iraqi students in February 2018 wherein they were asked to reflect on what they considered to be their daily jihads, or battles. The survey also sought to understand the extent to which Iraqi youth rely on faith or spiritual guidance to address their problems by seeking fatwahs from Islamic Jurisprudents, something which is considered to be commonplace in Shi'a majority countries such as Iraq and Iran. Additionally, the respondents were invited to suggest innovative ways in which present-day scholars might be able to reach out to the youth of Iraq more successfully. The brevity of the electronic questionnaire, together with its guaranteed anonymity, meant that the innermost thoughts of the participants were successfully secured through their surprisingly candid responses.

\section{MARĀJI \& TAQLĪD}

It was after the occultation of the Shi'a's present-day Imam, al-Mahdi, that a hawza, or seminary, was established in the city of Najaf in Iraq so as to offer guidance to the people. Since its inception over 1,000 years ago in 430AH (Ahlulbayt TV, 2013), the hawza has produced a series of learned scholars and highly respected jurisprudents, or Marāji, such as Sheikh Al-Mufid; Sheikh Al-Tusi; Allamah Al-Hilli; Sheikh Al-Khoei and, in the present day, Ayatollah Syed Ali Sistani (Ahlulbayt TV - The Historical Development of 
Shi'ism - Imams to Jurists, 2016). Much of the work of Marāji not only involves the explication of religious teachings and the promulgation of the Ahlulbayt, but also other contributions to social causes, including educational services. Some theological courses are part-funded through donations of khums (Islamic tax); for instance, the 20,000 students who attend the five-year hawza course in Najaf today in order to become Shi'a clerics receive a fully-funded bursary together with a small stipend for their studies (Ahlulbayt TV - The Grand Ayatollah, 2016).

While the primary role assumed by Marāji was traditionally to advise the lay public on religious matters, in recent years, and particularly since the two Gulf Wars and the subsequent demise of Saddam Hussain, these Marāji, or Islamic Scholars, have also been acting as political advisers with the restoration of stability in Iraq being one of their key aims.

The growing volatility in the country has spurred the creation of many extremist insurgent groups (Encyclopaedia Britannica, 2018a) like the Sunni fundamentalist militia, the Islamic State of Iraq \& the Levant (ISIL) ${ }^{2}$. The actions of these paramilitaries, combined with the Saudi-Western coalition since the early 1990s, has not only killed and maimed thousands of Iraqis and decimated the physical landscape of the country, but it has also bred feelings of disillusionment among its younger population, thereby requiring urgent action on the part of its leaders.

\section{THE HASHD AL-SHAABI FATWAH}

"And it is not for the believers to go forth [to battle] all at once. For there should separate from every division of them a group [remaining] to obtain understanding in the religion and warn their people when they return to them that they might be cautious."

[Al-Qur'an: Chapter at-Tawbah | Verse 122]

Since 2006, two representatives (namely Sheikh Abdul Mahdi Al-Karbalai and Syed Ahmad Al-Safi) of the present-day Shi'a Islamic Jurisprudent, Grand Ayatollah Syed Ali Sistani, have been author-

\footnotetext{
who also operate under alternative names and/or with other groups such as: Dā'ash; Daesh; Da'esh; ISIS; Islamic State; Islamic State in Iraq \& Syria; al-Dawlah al-Islāmiyyah fī al-'Irāq wa al-Shām
} 
ised to use their Friday sermons, delivered from the shrine of Imam Husayn $^{3}$ in the Iraqi holy city of Kerbala, to communicate with and guide the masses.

For many decades, Syed Ali Sistani was credited for his peace-making statements and the success of his efforts in limiting a civil war in Iraq by urging the population not to engage in battle or to resort to violence against forces occupying their land. However, it was in June 2014, once insurgents claiming allegiance to ISIL had overtaken the city of Mosul after defeating the Iraqi army, that the Popular Mobilisation Forces (PMF), or Hashd al-Shaabi fatwah was issued through a representative of the Grand Ayatollah. The PMF edict stipulated that irrespective of their religious affiliation, all healthy and able-bodied men in Iraq had a collective responsibility to help Iraqi Security Forces to fight against the fundamentalist group Da'esh so as to prevent the country from falling into further disarray (Morris, 2014). Since then, personnel from the holy shrines have worked closely with the Iraqi Ministry of Defense to ensure that volunteers who respond to the Hashd al-Shaabi edict are suitably equipped and given military training, plus psychological guidance on how to deal with enemy combatants (Watling, 2016).

Many Iraqi citizens have reportedly expressed enthusiasm about being given permission to engage in a holy war against the oppressors and tyrants who are destroying their country and people. Others state that they volunteered simply in order to restore stability and security in the region, rather than fighting on religious grounds. Either way, the number of annual casualties in Iraq is in the thousands:

As can be seen in figure 1 above, the number of civilian deaths in Iraq saw a sudden spike in 2014 when, together with Western invading armies, ISIL killed thousands of innocent civilians and forced an estimated half-a-million (BBC News, 2014) to flee to relative safety across Iraq, and/or to some of its slightly less politically-unstable countries along the border. Thus, there was a sense of predictability around the issuing of the Hashd al-Shaabi fatwah, particularly since earlier in the same year, the cities of Fallujah (Sly, 2014) and parts of Ramadi (The Telegraph, 2014) had also fallen to ISIL control.

O'Driscoll \& van Zoonen (2017) argue that the Hashd al-Shaabi edict was carefully worded along the lines of nationalism so as not to make it seem like a religious call to duty. However, some aspects

3 grandson of the Prophet Muhammad 


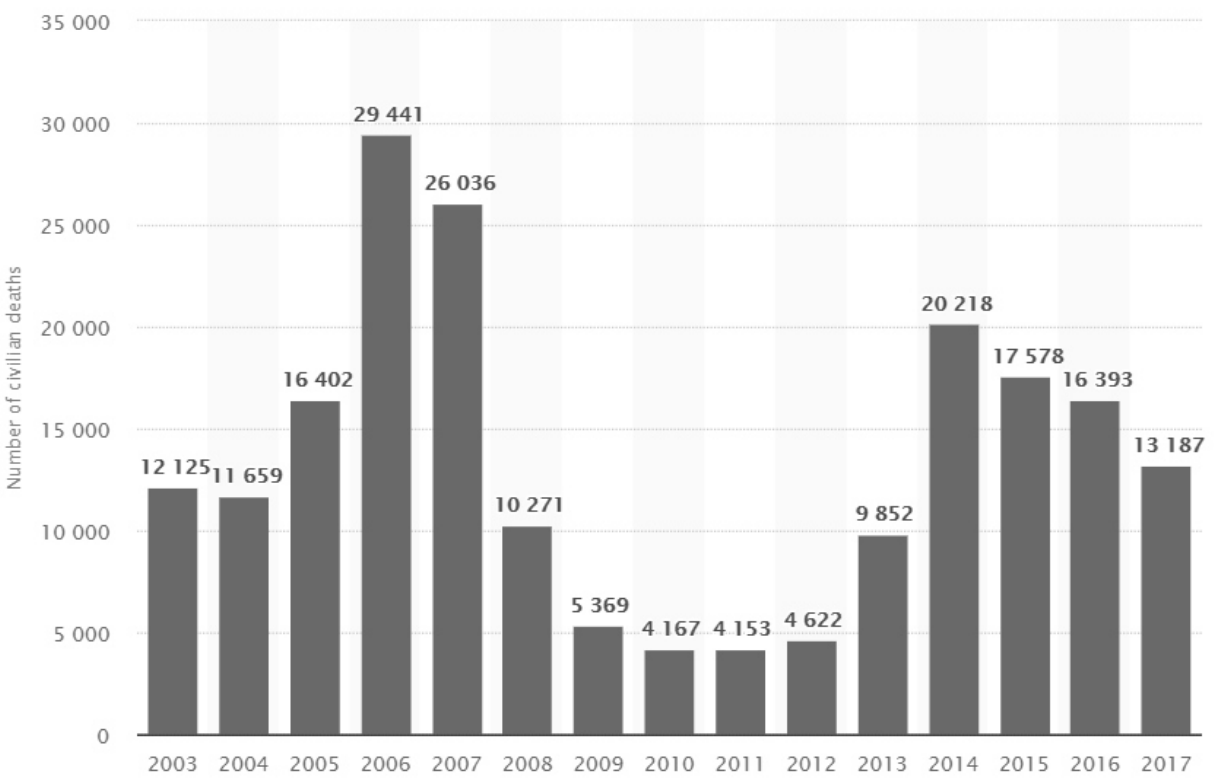

Figure 1: The Number of Recorded Civilian Deaths in Iraq 2003-17 (Statista, 2018)

of the fatwah are premised on Islamic principles. For instance, in February 2015, a statement was issued to soldiers which detailed 20 points, many of which were based on the teachings of the Holy Prophet (saw): its purpose was to instruct fighters on appropriate conduct in battle. One of the key pieces of advice that the statement included was: "do not indulge in acts of extremism" (Ahlulbayt TV The Grand Ayatollah, 2016)

The public response to the PMF edict was, some argue, greater than what was initially anticipated. It is estimated that between 100,000-152,000 volunteers (Al Jazeera, 2016) answered the fatwah in order to support Iraqi Security Forces. It did not go unnoticed that, as envisioned by Ayatollah Sistani, the volunteers consist of not only Shi'as, but also Sunnis, Christians and Yazidis:

A plethora of sub-state armed groups rapidly emerged and conglomerated under the banner of the Hashd al-Shaabi... Some groups were newly established, others reactivated or remobilised in response to Sistani's call after a period of inactivity. Others still were already active on the request of the then Prime Minister, Nouri al-Maliki, and used Sistani's call for legitimisation (Westcott, 2016 cited in O'Driscoll \& van Zoonen, 2017, p. 9). 
One of the sensitivities that currently surrounds this apparent show of unity, however, is that despite recognition of the PMF as a legal government entity, it embodies many different ideologies, some of which are purportedly in direct opposition to the Iraqi State, and each other; this points to an inevitable fear that this unity might only be short-lived. In some ways, the above is evocative of the manner in which forces passionately aligned with Mukhtar al-Thaqafi, an early Islamic revolutionary, in response to his call to avenge the killers of the Prophet Muhammad's grandson: Imam Husayn and his 72 companions were brutally slain on the plains of Kerbala in 66AH (AB Sites, 2011) by an army of 30,000 soldiers when the Imam tried to defend the true religion of his grandfather.

Tragically, the initial alliance of thousands belonging to splinter groups disintegrated when the supporters abandoned al-Thaqafi, prior to him having accomplished his mission. Thus, the fighters, who fractured into partisan entities with conflicting political goals and interests, were subsequently all left with diminished power and limited influence to succeed in their separate causes.

\section{THE RISE OF ATHEISM IN IRAQ}

Another possible threat to the current show of force through the Hashd al-Shaabi alliance comprising of Iraqi civilians is the surprising emergence of atheism among Iraqi youth (Nabeel, 2017). According to an investigation in early $2014,11 \%$ of Iraqis no longer believe in God (Salihi, 2014). The reasons that the youth gave to the investigator for their subversion included growing scepticism stemming from access to alternative information available on the internet and international TV channels; exposure to the ideologies and mind-set of secular nations through global travel; a desire to form a humanist rather than a sectarian identity; a distrust of politicians; feeling disillusioned by religious leaders; and a growing intolerance of violence and suffering caused in the name of religion.

While atheism is not against the law in Iraq, many of the young people who agreed to be interviewed for the above investigation in 2014 wanted to remain anonymous, or, assumed a pseudonym for fear of reprisals or rejection from their family, friends or community as most had not yet openly declared their atheism. Religious 'restrictions' were often cited as being the cause of growing despair among 
other Iraqi youth, particularly when they were repeatedly warned by parents and peers about the prospect of entering the hellfire for failing to adhere to Islamic teachings. In a separate investigation, a reporter for the Baghdad Post (2017) was told of what was perceived to be the hypocrisy of Shi'a militia who killed fellow Iraqis, and then visited the holy shrines of Imam Ali in the city of Najaf and Imam Husayn in Kerbala, with many partaking in the $80 \mathrm{~km}$ Arba'een walk, an annual pilgrimage, from Najaf to Kerbala.

According to a reporter for The New Arab (Browne, 2016), Iraq is seeing a gradual growth in the number of 'atheist sleeper cells' comprised of small groups of academics, students and/or government employees who meet regularly in clandestine locations across the country to discuss philosophy and secularism. They voice an increasing level of disgruntlement at what they consider to be the incompetence of the Iraqi government and the prohibitions that Islam and Islamic Scholars place on its followers.

The so-called oppression of women in Islam through the enforcement of hijabs, burkhas, and limits to their social freedom/choices, is also referred to by some as a reason for leaving the religion. It was in late 2016 that Ammar al-Hakim, the leader of the Iraqi National Alliance party, stated that atheists in the country should be confronted with 'iron fists' for disseminating anti-Muslim ideas across Iraq (Mamouri, 2017).

In an attempt to understand how widespread each of the aforementioned concerns are, or the extent to which they are representative of the views of Iraqi youth today, I conducted an empirical study of my own in the form of an online questionnaire which was issued to Iraqis between the ages of 18 and 45 .

The section that follows outlines the research methodology that was employed for this study, including the questions that were posed to participants, and the rationale behind the same. This is followed by the findings of the research.

\section{EMPIRICAL STUDY - METHODOLOGY}

The main aim of this study was to establish what the Iraqi youth of today think of Islamic Jurisprudents, or Marāji, and the edicts they issue, and, how these correlate with the matters that are of concern to Iraq's young population. I also wanted to establish how many of the respondents consulted an official Mujtahid or the services pro- 
vided through his office, and the frequency with which they did this. One of the questions prompted the youth to consider the clarity of the edicts issued by asking them to rate these on a five-point scale where 1 meant "not at all clear" while 5 meant "completely clear." The respondents were asked to identify three matters which they considered to be of greatest importance to the young population of Iraq today. The participants were also urged to suggest ways in which Marāji could gain better access to Iraqi youth - both literally and mentally.

The online survey was created using Google Forms to allow for the swift and anonymous distribution of the questionnaire via an electronic link ${ }^{4}$ (accessible here: https://goo.gl/forms/ZmCGHcwYPEKucreG3). This not only provided an effective way of collecting data at no cost to anyone involved, but was also efficient when managing different time zones. Additionally, Google Forms gives the option of rendering the results of multiple-choice questions into an easy to read format by creating graphical representations like pie charts and bar graphs, while also conveniently populating a spreadsheet. A conscious effort was made to keep the questionnaire both short and reasonably simple so as to encourage more respondents to complete it: there were a total of five content-based questions related to the topic. The first three questions required answers to be selected from a list (i.e.: multiple-choice options), while the two subsequent questions were open-ended, with an optional follow-up. The survey ended with a request for respondents to identify their gender, age, where they were currently residing, and whether they followed a Mujtahid, or Scholar.

\section{QUESTIONNAIRE FINDINGS}

A total of 78 Iraqi respondents completed the questionnaire, 75 of whom were Shi'a. 76 participants answered the questions between the dates of 2nd and 8th of February 2018, followed by a further two, one each in the months of March and April 2018. The majority of respondents reside in Iraq, while some are currently studying abroad, namely in Australia, Sweden, the USA and the UK. Most answered all of the questions. The profile of the participants can be

4 with thanks to Abeer Jameel, Iraqi PhD student in the UK, for disseminating this questionnaire to her contacts 
seen in figures 2 and 3 below, whereby 74 of the 78 respondents provided responses to these prompts for demographic information:

\section{QUESTIONS RESPONSES 78}

Demographic Information (anonymous): Are you male or female?

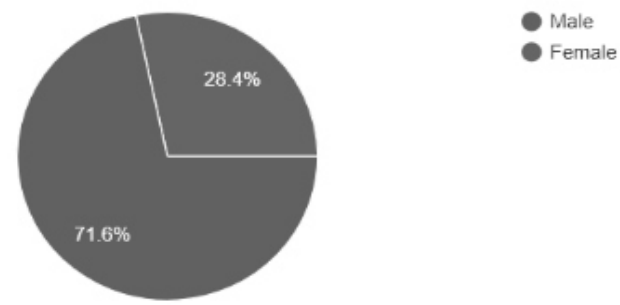

FIGURE 2: GENDER OF RESPONDENTS

It is not known for certain whether the greater number of male respondents, as can be seen in figure 2 above, is a point of significance for this questionnaire. That is, some may argue that the forthright responses to some of the questions (which will be seen later) can be attributable to the large male contingent of those who participated in the research. Perhaps the men felt more confident or comfortable about being candid than the women, or conversely, less apprehensive about responding to questions regarding how (or indeed whether) they practised their faith with the aid of a Mujtahid, and what the perceived problems of the system of taqli $\mathrm{i}^{5}$ may be. The Encyclopaedia Britannica (2018b) defines taqlīd as "the unquestioning acceptance of the legal decisions of another without knowing the basis of those decisions."

also spelt taqleed 
Which age bracket are you in:

74 responses

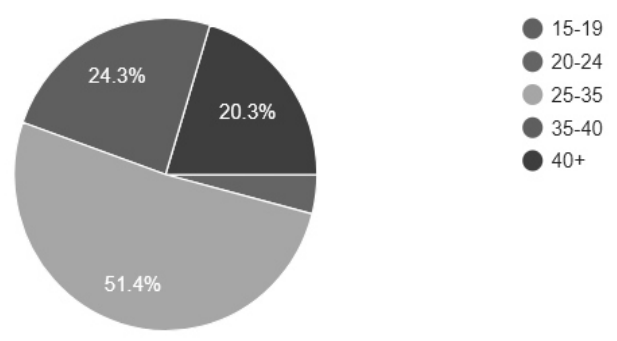

FIGURE 3: AGE OF RESPONDENTS

Similarly, the probable maturity of those over the age of 25 could have been a contributory factor in their decision to provide answers to what some might perceive to be a sensitive or even controversial topic. This argument seems plausible to a large degree, for when individual responses to each question were examined, it was indeed noted that the respondents in the 25-35 and 35-40 age bracket, particularly the males, were notably more direct than their female counterparts in their response to the two questions requiring open answers.

What follows, is the findings for the main questions.

\section{QUESTIONS RESPONSES 78}

1. How many times have you contacted your Mujtahid (or his representative) for guidance in the last 12 months?

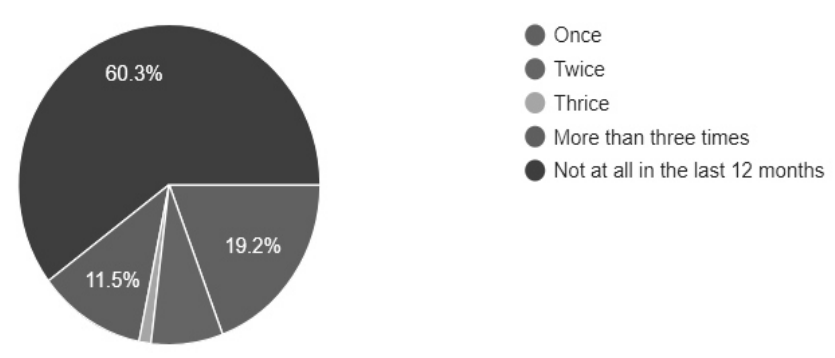

FIGURE 4: FREQUENCY OF CONTACT WITH MUJTAHID 
It can be seen from figure 4 above that a sizeable proportion of the respondents, that is, $60.3 \%$ (i.e.: 47 out of 78), made no attempt to contact a Mujtahid in the last 12 months. This was contrasted with 11.5\% (i.e.: 9 respondents) who consulted Marāji on more than three occasions. The number who said that they had approached a Mujtahid for guidance once in the last year equated to $19.2 \%$ (i.e.: 15 people).

When the respondents were asked to comment on the clarity of the edict(s) passed by Marāji in general today, their results varied, as evidenced in figure 5 below: $19.2 \%$ (i.e.: 15 people) rated the fatwahs as being completely clear, compared with $30.8 \%$ (i.e.: 24 respondents) who felt the edicts were not at all clear. Nearly a quarter of the respondents $(24.4 \%)$ categorised the fatwahs as fairly clear.

2. On a scale of 1 to 5 (where $1=$ not at all clear $\& 5=$ completely clear), generally, how clear do you find the edicts issued by Mujtahid today?

78 responses

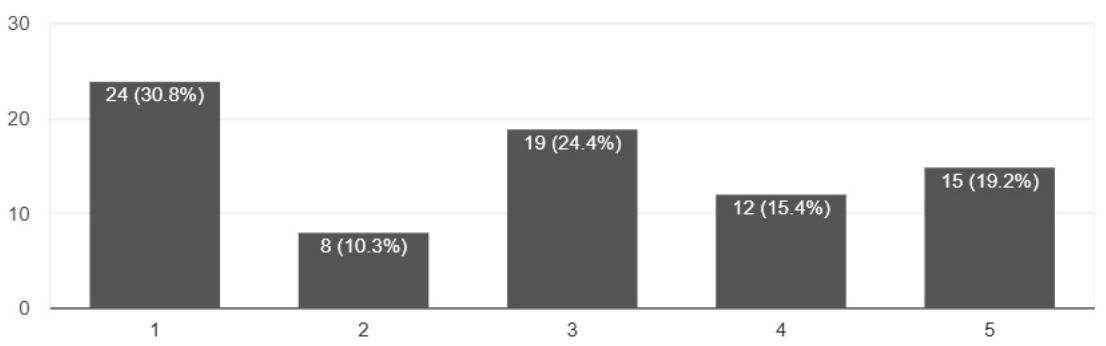

FIGURE 5: CLARITY OF RESPONSES FROM MUJTAHID

Considering that one of the primary roles of Marāji is to guide their followers - or muqalids, by providing an exegesis of the teachings of Islam, the results for question two warrant reflection and possible action. Either the Marāji need to consider alternative ways of communicating their edicts to the lay public, and/or, the latter need to be trained to better understand the fatwahs so as to derive the intended benefit from them. Respondents who felt that the edicts issued by Marāji were unclear were asked to propose solutions to this problem by suggesting ways in which better communication could take place with the people. The results for this part of the questionnaire will be revealed in table 2 of this paper. 
3. Do you consult the edicts/materials/Q\&A/e-books that are available online by the official office/representatives of your Mujtahid?
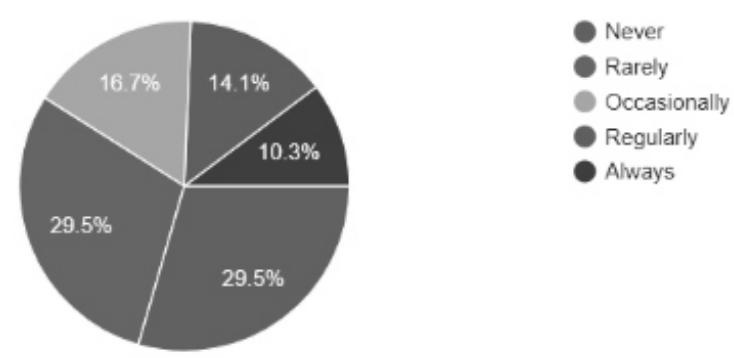

FIGURE 6: BREAKDOWN OF SOURCES OF RELIGIOUS GUIDANCE OFFERED BY MUJTAHID

The responses to question 3 varied. Figure 6 shows that close to one third of the respondents said they never consulted the online support offered by the office of their Mujtahid, followed by a further $29.5 \%$ who said they rarely did so. The likely reason behind these figures need consideration. A number of possibilities exist, some of which appear probable, while others can be inferred as highly likely given the responses. For instance, those respondents who indicated in a later question that they did not follow Marāji clearly have no use for the online resources that may be on offer through a dedicated website of a Mujtahid.

In the case of those respondents who have opted for taqlid, yet rarely or only occasionally consult the materials online, this may, in part, be due to limited resources being available on the website of their chosen Mujtahid. Indeed, this is a point which I noted when comparing the websites of three Marāji in Iraq: the online resources offered by the office of Ayatollah Syed Ali Sistani is by far the most comprehensive in the range of support that is provided. Nevertheless, even a large proportion of Ayatollah Sistani's followers who responded to this questionnaire said they rarely visited his website.

Question 4 was the first of two open-ended questions in the survey. Respondents were asked to list the three things which they considered to be of greatest concern to Iraqi youth today. An interesting range of answers were given. While all 78 respondents answered this question, not everyone listed three matters of concern. Table 1 shows the issues that were highlighted, and by how many people, listed in order of frequency, while table 2 contains the 
suggestions of respondents as to how spiritual leaders might better connect with Iraqi youth today:

\begin{tabular}{|l|l|}
\hline \multicolumn{1}{|c|}{ ISSUES OF CONCERN TO IRAQI YOUTH TODAY } & $\begin{array}{c}\text { NUMBER OF RESPOND- } \\
\text { ENTS }\end{array}$ \\
\hline unemployment & 33 \\
\hline ISIS/insecurity in Iraq/future of the country & 25 \\
\hline religion vs. freedom & 21 \\
\hline education & 15 \\
\hline marriage & 15 \\
\hline weak economy & 14 \\
\hline politics/government corruption & 11 \\
\hline appropriate Islamic conduct (e.g.: hijab; tattoos; hair-cuts) & 8 \\
\hline moral corruption (e.g.: drugs; alcohol; external influences) & 6 \\
\hline sex-related matters & 6 \\
\hline social media \& enhanced technology & 6 \\
\hline poor services/infrastructure & 5 \\
\hline family \& friends & 3 \\
\hline inter-faith dialogue & 3 \\
\hline miscellaneous (e.g.: car; banking; mental well-being; fame) & 8 \\
\hline
\end{tabular}

TABLE 1: RESPONSES TO QUESTION 4 - ISSUES OF CONCERN TO IRAQI YOUTH

It is perhaps of little surprise that the political insecurity in Iraq linked to ISIS featured among the top three concerns for Iraqis in this research. It was unemployment, which has arguably been exacerbated by instability in the country that was the main issue listed by 33 out of 78 respondents. The third most popular response to this question was religion and wanting to think and behave with freedom. This seems to part corroborate the reports (Salihi, 2014; Baghdad Post, 2017) referred to earlier herein which suggest that a steadily growing number of Iraqis are becoming disillusioned by their religion, with some even turning to atheism. Several respondents criticised the perceived infallibility of Marāji and not being able to challenge or question the edicts they issue.

The next three items, namely education, marriage and the economy, received almost equal priority as points of concern for young Iraqis today. Table 2 reveals what participants suggest as possible 
solutions for enhanced communication between Marāji and the people:

\begin{tabular}{|l|l|}
\hline \multicolumn{1}{|c|}{ SUGGESTIONS FOR MARĀJI TO BETTER CONNECT WITH THE YOUTH } & \multicolumn{1}{c|}{$\begin{array}{c}\text { NUMBER OF } \\
\text { RESPONDENTS }\end{array}$} \\
\hline use social media \&/or online discussions & 28 \\
\hline show more humility & 8 \\
\hline understand the mind-set of the youth & 8 \\
\hline visit educational establishments \& give live talks & 7 \\
\hline engage in two-way communication \& respect & 7 \\
\hline don't know/nothing can be done & 7 \\
\hline address inconsistencies among Marāji & 6 \\
\hline miscellaneous (e.g.: TV shows; improve websites; be organised) & 6 \\
\hline
\end{tabular}

TABLE 2: RESPONSES TO QUESTION 5 - SUGGESTIONS FOR MARĀJI

It comes as little surprise that the respondents overwhelmingly suggested the use of social media to reach out to Iraqi youth. This included online discussion forums (for instance, live chats). A number of participants indicated that there was a mismatch between Marāji and contemporary youth due to the former not fully understanding - nor endeavouring to understand the mind-set of the latter and the issues which are pertinent to them today. Better two-way communication and evidence of mutual respect was also being sought. Additionally, there was reference to out-datedness in relation to some of the edicts and the matters focused on by most Marāji of our time, implying that many are out of touch with the true concerns of youngsters. Some respondents also argued that religion and the State should be kept separate, but felt this was not the case in Iraq. Seven people appeared despondent regarding possible solutions.

An optional follow-up to the prompt for suggestions that might result in improved interactions between spiritual leaders and their followers, was for respondents who were personally unhappy with their Mujtahid, or Marāji in general, to propose solutions to this problem. 13 out of 78 respondents offered a response to this, although four simply wished to reiterate that they were happy with their chosen Mujtahid. One stated that s/he did not understand 
what was meant by 'unhappy' in the context of this question. The other eight gave the unedited individual responses shown in table 3:

SUGGESTIONS FROM RESPONDENTS WHO ARE PERSONALLY UNHAPPY WITH MUJTAHID/MARĀJI

"Secular ideas are far better than the ones Islam is providing"

"The Mujtahids should fight against sectarianism too by releasing fatwa against sectarianism and make it haram. Secondly religious leaders and Mujtahids should not be sacred. It should be ok to criticise them. Because they are the most corrupt groups in Iraq right now" "educate people"

"Use my brain in scientific way, because I am responsible on myself in front of Allah"

"Seek higher knowledgeable one"

"Not to follow and change it because to follow a certain world is personal freedom, especially the presence of more world and more than one direction"

"Well, sometimes it is difficult to accept some ideas from the Mujtahids point of view. If I were in Mujtahids shoos I properly make public meeting and make better communications with the society to share ideas and help to improve the society"

"You can be with another one"

TABLE 3： RESPONDENTS PERSONALLY UNHAPPY WITH MUJTAHID/ MARĀJI

Table 4 which follows shows the number of respondents in this research who currently opt for the taqlid of a Mujtahid; 74 out of 78 responded to this question:

\begin{tabular}{|l|l|}
\hline \multicolumn{1}{|c|}{ MUJTAHID FOLLOWED BY RESPONDENTS } & \multicolumn{1}{c|}{$\begin{array}{c}\text { NUMBER OF } \\
\text { RESPONDENTS }\end{array}$} \\
\hline Ayatollah Syed Ali Sistani & 35 \\
\hline None & 30 \\
\hline Sunni doctrine & 3 \\
\hline Al-Qur'an & 1 \\
\hline Osama Al-Mawali & 1 \\
\hline Abu al-Qasim al-Khoei & 1 \\
\hline Mohammad Sadiq al-Sadr & 1 \\
\hline Local Mujtahid & 2 \\
\hline
\end{tabular}

TABLE 4: CHOSEN MUJTAHID OF RESPONDENTS 
As can be seen, the vast majority of respondents $-47 \%$ of all those who completed the questionnaire - have opted for the taqlid of Ayatollah Syed Ali Sistani. What is noteworthy is that when the individual responses of all those who identified Syed Sistani as their Mujtahid were examined in detail across the questionnaire, in general, it was found that these respondents are content with the fatwahs he passes, and the clarity of the same: they expressed confidence in his teachings and religious expertise. However, as can be seen in table 4, almost an equal proportion of respondents said that they did not follow any Mujtahid at all, as they preferred to use logic and rational thinking to make their decisions and choices in life.

CONCLUSION To summarise, this paper has attempted to outline the changing perceptions of contemporary Iraqi youth and the significance of religion, specifically the taqlīd of a Mujtahid, in their lives today. Data gathered through the empirical research conducted in early 2018, primarily in February, shows that there was a mixed response to religious edicts and their perceived level of ambiguity. When respondents were asked to comment on the extent to which Marāji address the concerns of Iraqi youth nowadays, the initial impression was that there is a mismatch between the matters that are of importance to youngsters versus the focus of the religious scholars. Consequently, many of the respondents had opted out of the practice of taqlid, preferring instead to have the freedom to rely on their own judgements and decision-making. What none of the participants appeared to reflect on, and perhaps ought to have been included as an explicit question for non-atheists, was the extent to which they felt confident about interpreting religious scriptures without guidance and/or affirmation from a learned scholar or official jurisprudent. The full set of responses provided by three of the participants hinted at their possible atheism.

Closer examination of the results, however, indicated an interesting pattern, and one which may be different to what appears to first meet the eye. The three main areas of concern for the Iraqi youth as outlined by the respondents of the anonymous online questionnaire were: unemployment, ISIS/insecurity in Iraq/future of the country, and religion. When this is cross-referenced with the edicts being passed by the leading Mujtahid of Iraq today, the Grand Ayatollah Syed Ali Sistani, whom approximately half of the respondents follow, it might be argued by some that he is addressing the points that 
are of concern to Iraqi youth - through his Hashd al-Shaabi fatwah. This is not a sectarian edict; on the contrary, its purpose is to restore stability in Iraq through the abolition of the fundamentalist militia, ISIL.

Hence, in fact, some of the apparent disillusionment of the youth might be deemed misplaced because the religious and political leaders of the country are demonstrating their mindfulness of the social issues that are of concern. To conclude, perhaps greater use of contemporary methods of communication, for instance - social media, might instil more confidence in the hearts and minds of young Iraqis today as regards their Marāji and the edicts issued they issue.

REFERENCES AB Sites (2011). Mukhtar Saghafi. Available from: http://ahlulbaytportal.net/en.php/page,24916A48261.html [Accessed on 18 February 2018]

Al Jazeera (2016) \& Westcott (2016). cited in O’Driscoll, Dylan \& van Zoonen, Dave (2017, p. 9). 'The Hashd al-Shaabi and Iraq Subnationalism and the State.' Middle East Research Institute. Available from: http://www.meri-k.or g/wp-content/uploads/2017/06/Hashd-Alshaabi-report.pdf [Accessed on 17 February 2018]

Baghdad Post (2017, 11 Jan). Iraq suffers from spread of atheism due to religious extremism. Available from: http://www.thebaghdadpost.com/en/sto ry/4938/Iraq-suffers-from-spread-of-atheism-due-to-religious-extremism [Accessed on 15 February 2018]

Bassem, W. (2014, 16 Oct). 'Drug use spreads among Iraqi youth.' Al-Monitor. Available from: https://www.al-monitor.com/pulse/originals/2014/10/ira qi-youth-drug-addiction-escape-security-social-problems.html [Accessed on 3 February 2018]

BBC News (2014, 11 Jun). Iraq crisis: Islamists force 500,000 to flee Mosul. Available from: http://www.bbc.co.uk/news/world-middle-east-27789229 [Accessed on 15 February 2018]

Browne, G. (2016, 31 Oct). 'Iraq's new atheism in the shadow of Islamic State.' The New Arab [Online]. Available from: https://www.alaraby.co.uk/english/ indepth/2016/10/31/iraqs-new-atheism-in-the-shadow-of-islamic-state [Accessed on 15 February 2018]

Encyclopaedia Britannica (2018a). Islamic State in Iraq and the Levant. Available from: https://www.britannica.com/topic/Islamic-State-in-Iraq-and-t he-Levant [Accessed on 20 February 2018]

Encyclopaedia Britannica (2018b). Taqlid - Islaimic Law. Available from https://www.britannica.com/topic/taqlid [Accessed on 14 August 2018] 
Mamouri, A. (2017, 22 Jun). 'Islamic parties intimidate, fear atheists in Iraq.' Al-Monitor. Available from: https://www.al-monitor.com/pulse/originals/ 2017/06/iraq-atheism-political-islam-human-rights.html [Accessed on 15 February 2018]

Massella, A. (2017, 19 Oct). 'We Have Forgotten What Happiness Is: Youth perspectives on displacement and return in Qayyarah sub-district, Mosul.' Oxfam - Policy \& Practice Report. Available from: https://policy-pract ice.oxfam.org.uk/publications/we-have-forgotten-what-happiness-is-yout h-perspectives-on-displacement-and-retu-620351 [Accessed on 3 February 2018]

Morris, L. (2014, 13 Jun). 'Shiite cleric Sistani backs Iraqi government's call for volunteers to fight advancing militants.' The Washington Post [Online] Available from: https://www.washingtonpost.com/world/middle_ea st/ volunteers-flock-to-defend-baghdad-as-insurgents-seize-more-iraqi-territ ory/2014/06/13/10d46f9c-f2c8-11e3-914c-1fbd0614e2d4_story.html?utm_t erm $=.35$ e7446060a5 [Accessed on 20 February 2018]

Nabeel, G. (2017, 1 Aug). 'Atheists in Muslim world: Silent, resentful and growing in number.' The Washington Post [Online]. Available from: https:// www.washingtontimes.com/news/2017/aug/1/atheists-in-muslim-world -growing-silent-minority/ [Accessed on 15 February 2018]

O’Driscoll, D. \& van Zoonen, D. (2017). 'The Hashd al-Shaabi and Iraq Subnationalism and the State.' Middle East Research Institute. Available from: http://www.meri-k.org/wp-content/uploads/2017/06/Hashd-Alshaabi-re port.pdf [Accessed on 17 February 2018]

Salihi, M. (2014, 5 Feb). 'The Death of God in Iraq: 32\% of Iraqis not Sure God Exists, 11\% think Not.' Informed Comment. Available from: https://www.ju ancole.com/2014/02/death-iraqis-exists.html [Accessed on 15 February 2018]

Sly, L. (2014, 3 Jan). 'Al-Qaeda force captures Fallujah amid rise in violence in Iraq.' The Washington Post [Online]. Available from: https://www.washingt onpost.com/world/al-qaeda-force-captures-fallujah-amid-rise-in-violence -in-iraq/2014/01/03/8abaeb2a-74aa-11e3-8def-a33011492df2_story.html?u tm_term $=.4$ d6cdab95282 [Accessed on 18 February 2018]

Statista (2018). Number of documented civilian deaths in the Iraq war from 2003 to December 2017. Available from: https://www.statista.com/statist ics/269729/documented-civilian-deaths-in-iraq-war-since-2003/ [Accessed on 15 February 2018]

Taki, A. (Executive Producer) (2016). The Grand Ayatollah. Ahlulbayt TV Documentaries. Available from: https://www.youtube.com/watch?v=qbzBJIWNorc [Accessed on 3 February 2018] 
Taki, A. (Executive Producer) (2016). The Historical Development of Shi'ism Imams to Jurists. Ahlulbayt TV Documentaries. Available from: https:// www.youtube.com/watch?v=5blo0E-Zhi8 [Accessed on 14 February 2018]

Taki, A. (Executive Producer) (2013). The Seminary - The Hawzah in Najaf. Ahlulbayt TV Documentaries. Available from https://www.youtube.com/wat ch?v=GFhpPa-uivM [Accessed on 18 February 2018]

The Telegraph (2014, 4 Jan). Fallujah falls under Al-Qaeda control in blow for Iraq security. Available from: http://www.telegraph.co.uk/news/worldnews/middleeast/iraq/10550563/Fallujah-falls-under-Al-Qaeda-control-in -blow-for-Iraq-security.html [Accessed on 18 February 2018]

UN Assistance Mission for Iraq (2017, 24 May). Hopeful Iraqi Youth Propose Solutions, Air Concerns as they Conclude Forum on Promoting Coexistence and Reconciliation [EN/AR]. Available from: https://reliefweb.int/report/ iraq/hopeful-iraqi-youth-propose-solutions-air-concerns-they-conclude-f orum-promoting [Accessed on 3 February 2018]

Watling, J. (2016, 22 Dec). 'The Shi'a Militias of Iraq.' The Atlantic. Available from: https://www.theatlantic.com/international/archive/2016/12/Sh i'a-militias-iraq-isis/510938/ [Accessed on 20 February 2018]

Williams, S. (2017, 21 Oct). Iraq's lost generation: 'I have forgotten what happiness is'. Guardian [Online]. Available from: https://www.theguardian.com/world/2017/oct/21/iraq-mosul-lost-generation-isis-forgotten-ha ppiness [Accessed on 3 February 2018]

\section{СОФИЈА БАТ}

МЕЋУНАРОДНИ КОНСУЛТАНТ ЗА ВИСОКО ОБРАЗОВАҢЕ

УНИВЕРЗИТЕТ У БИРМИНГЕМУ

РЕЗИМЕ

О ФАТВАМА И ДИЛЕМАМА МЛАДИХ ИРАЧАНА

Муслимани верују да откровења и изреке Пророка Мухамеда представљају код за живот на овоме свету, и оном другом. Преко Курана, Пророка и Пророковог потомства, Алах је обавестио муслимане о дужности да следе знање, али и да мудро поступају у складу с њим. Да би поступили у складу с овом заповешћу, следठеници ислама који настоје да проникну у тајне Светих списа с дужном пажњом, уједно увиђају границе својег знања, чак и током покушаја да дешифрују наизглед једноставне стихове у Курану због сложености њихове егзегезе. Стога, за разлику од сунита, шиитски следбеници Ехли-бејта пажњу поклањају важности и неопходности таклида (taqlid) - односно, обраћају се 
познаваоцима права за учено тумачење Светих текстова, учења Пророка Мухамеда и ठезгрешних потомака његове кћери Фатиме аз-Зехре. Међутим, у којем су обиму едикти, или фатве, које издају савремени познаваоци исламског права у складу са веровањима и дилемама савремене младежи, нарочито ирачке?

КљУчнЕ РЕчи: исламско право; Marāji (титула у значењу: „онај кога треба следити“); Mujtahid (титула у значењу: „онај који улаже напор да реши проблем“); едикти; фатве; таклид; млади у Ираку; дилеме.

Овај чланак је објављен и дистрибуира се под лиценцом Creative Commons Ауторство-Некомерцијално Међународна 4.0 (CC BY-NC 4.0 | https://creativecommons.org/licenses/by-nc/4.0/). This paper is published and distributed under the terms and conditions of the Creative Commons Attribution-NonCommercial International 4.0 licence (CC BY-NC 4.0 | https://creativecommons.org/licenses/by-nc/4.0/). 